\title{
培養した薄状軟組織の押込みによる柔さ計測
}

Measurement of the Softness of Thin Sheet of Cultured Soft Tissue by Indentation

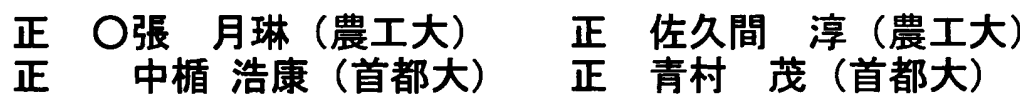

Yuelin ZHANG, Tokyo University of A\&T, 2-24-16 Nakacho, Koganei, 184-8588, Tokyo Atsushi SAKUMA, Tokyo University of A\&T

Hiromichi NAKADATE, Tokyo Metropolitan University, 6-6 Asahigaoka, Hino, 191-0065, Tokyo Shigen AOMURA, Tokyo Metropolitan University

Key words : $\quad$ Material Testing, Thin Sheet, Softness, Cultured Soft Tissue, Indentation

\section{1. 赫}

人間の頭部に何らかの衝恤が加わった場合, 譄には様々な 損伤が起きる.これらの損傷に対する迅速な救急処置, さら には後造症患者に適切な治療を施すために, 脳損伤の発症機 序を解明することによって症状を正しく予測する必要があ る.これまで, 頭部外伤の発症メカニズムを解明するために, 著者らは, 頭部有限要素モデルを用いた頭蓋内の力学応答解 析(1)および培養した神経細胞を用いた重慗実験 ${ }^{(2)}$ を実施して いる．しかし，培養した神経細胞を用いた衝慗実験時の赛験 条件と頭蓋内の神経細胞の生存条件は異なり，培養した神経 細胞で得られた外部入力と損賃の関保をそのままヒト受賃 度の評価に利用できなく，早期診断に用いることができない. つまり，外部入力と神経損賃の関係を評価するには，神経線 維の適切なモデルを構築し，現存の頭部モデルに組込む必要 がある．そのため, 神経線維の微視レベルの力学的特性を明 らかにすることが求められている.

ここで,これまでに培養した神経線維および神経線維を含 めた組織の厚さは mm オーダー未满のものが多く, 薄いシー ト状のものの力学的特性を計测するために, 原子間力顕微鏡 (AFM) ${ }^{(3)}$ や張試験(4)を用いた研究が行われている. そこで 本研究では，ディッシュ等で培養したままの状態で，試料を 取り出す必要のない球圧子押込試験法()を用いて，微視レベ ルの神経線維の力学的特性を高精度に計測することを目的 とする. 本報では，球圧子押込試験を厚さが $\mathrm{mm}$ オーダー未 満の薄状試料一適用する計测原理と計测結果を報告する.

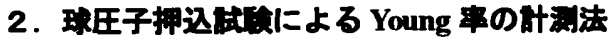 \\ 2.1Hertz の蒀性接位理"}

Hertz の弾性接触理論(のおいて, 半無限体試料に対して十 分に硬い球圧子を押込むとき, 球圧子の直径 $\phi$ と試料 Young 率 $E$, ポアソン比 $v$ を用いて，押込荷重と押込量 $\delta$ の関俰を 式(1)で表現できる.

$$
F=\frac{4}{3} \frac{E}{1-v^{2}}\left(\frac{\phi}{2}\right)^{\frac{1}{2}} \delta^{\frac{3}{2}}=A \delta^{\frac{3}{2}}
$$

薄い試料の荷重 $\hat{F}$ は試料厚さの影響を受けるが,この影響を 示す係数 $B$ を用いた次式による近似を実施する().

$$
\hat{F}=A\{\delta(1+B \delta)\}^{\frac{3}{2}}=\hat{A} \delta^{\frac{3}{2}}
$$

この式を用いる場合, 試料の Young 率に関して以下の関係が 成立することとなる.

$$
\hat{E}=E(1+B \delta)^{\frac{3}{2}}
$$

これは, 試料本来の Young 率 $E$ に対して薄い試料の計測値 $\hat{E}$ が高くなることを示している.

そこでこの現象を利用して, Young率 $\hat{E}$ の 2 次導関数 $\hat{E}^{\prime \prime}$ と 試料厚さ $h$ について関数 $f$ を得ることができれば，接触開始 時の情報から試料厚さ $h$ の演繹が可能となる.ここで今回の 結果を吟味したところ指数関数的関係を示したことから，次 式によって試料厚さ $h$ を同定することとする.

$$
h=f\left(\hat{E}^{\prime \prime}\right)=H \ln \left(\frac{G}{\hat{E}^{n}}\right)
$$

なお, 係数は $H=2.16 \times 10^{-3} \mathrm{~m}, G=3.76 \times 10^{9} \mathrm{~Pa} / \mathrm{m}^{2}$ となっ ている.

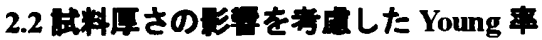

有限体試料では圧子の押込部で試料が著しく変形する現 象が観られることから, 本研究では押込変形を接触変形と圧 縮変形の効果を重ね合わせることを考える(す). 接触の効果は Hertz の接触理論から算出するひずみ $\bar{\varepsilon}_{\mathrm{H}}$ で表現し, さらに圧 樎は試料の軟らかさによる圧縮変形の領域体積の変化率 $\bar{\varepsilon} \mathrm{V}$ で表すものとして，次の関係を定義する。

$$
\bar{\varepsilon}_{1}=\bar{\varepsilon}_{\mathrm{H}}+\bar{\varepsilon}_{\mathrm{V}}
$$

この $\bar{\varepsilon}_{1}$ は, 押込過程で試料中に生じる 3 次元的なひずみ分 布を等価的な単軸ひずみで表そうとしたものである. 詳細に ついては紙面の都合上割愛するが, 圧縮変形を受ける領域を 圧子と試料底面に挟まれた楕円領域と仮定することでこの ひずみ $\bar{\varepsilon}_{\mathrm{I}}$ を次式で表現する。

$$
\bar{\varepsilon}_{\mathrm{I}}=-\frac{2}{\pi\left(1-v^{2}\right)}\left(\frac{2 \delta}{\phi}\right)^{\frac{1}{2}}-\frac{\delta}{h}-\frac{2}{3} \ln \left\{\frac{2 h+3\left(\frac{\phi}{2}-\delta\right)}{2 h+\frac{3}{2} \phi}\right\}
$$

これが単軸変形を等価的に表現できるとすれば, 試料に生じ た応力 $\sigma=E \bar{\varepsilon}_{1}$ の関係を想定できる. さらに接触部で Hertz の忘力分布を同時に考えることが可能であれば, 試料の Young 率 $E$ は次式で導出可能となる.

$$
E=-\frac{6}{\pi^{3}\left(1-v^{2}\right)^{2}}\left(\frac{2}{\phi}\right)^{2} \frac{\hat{F}}{\bar{\varepsilon}_{\mathrm{I}}^{3}}
$$




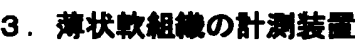

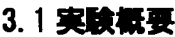

多様な薄状軟組織を評価するために, 押し込み深さ $10 \mu \mathrm{m}$ まで測定できる(株)島津製作所社製ダイナミック超微小硬度 計 DUH-211(試験力の测定最小単位 $0.196 \mu \mathrm{N}$ )を用いた. 計測 装㯰の外観を図 1 に示す.

計測に用いる供試材には，市販で特性が安定している硬度 は A50 のシリコーンゴムシートを用いた．シートの厚さは $0.1 \mathrm{~mm}$ と $0.2 \mathrm{~mm}$ で一辺 $10 \mathrm{~mm}$ の正方形状のものを使用した. 押込試験において, 直径が $1 \mathrm{~mm}$ のダイヤモンド $(E=1.14 \times$ $\left.10^{12} \mathrm{~Pa}, v=0.07\right)$ の球圧子を用いた。試供材の粘性の影響を 低減するために，荷重の負荷速度を装置仕様で最も低速な $0.0015 \mathrm{mN} / \mathrm{sec}$ とする. 試験時の環境条件は気温 $18.8^{\circ} \mathrm{C}$, 湿度 $53 \%$ であった.

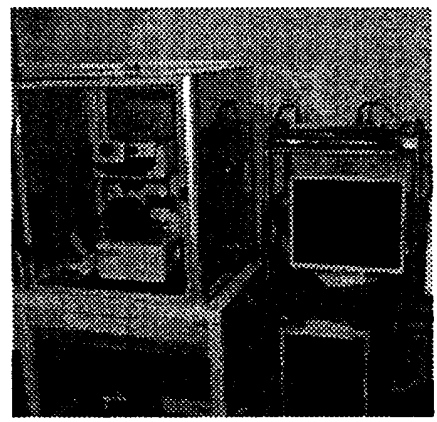

Fig.1 Measurement Equipments of Thin Soft Tissues. Dynamic Ultra Micro Hardness Tester DUH-211 of Shimadzu Corp. (Low Test Force with Measurement Resolution of $0.196 \mu \mathrm{N}$ ).

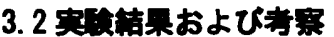

実験より得られた押込荷重と押込量の関係およびそれに よって同定した Young 率の結果を図 2 に示す. 同定した Young 率とデュロメーター硬さを Young 率に換算した(7)結果 を表 1 に示す.

各実験結果において，押込量が $0.4 \mu \mathrm{m}$ になるまでの荷重 と押込量の関俰を用いて Young 率を同定した. 図 2 では, 実 験結果を稩い実線，同定した近似線を太い実線で示している， 同定した結果，本実験で用いたシリコーンゴムシートの Young 率は $0.1 \mathrm{~mm}$ と $0.2 \mathrm{~mm}$ の両方においてともに $8.46 \mathrm{MPa}$ であった. Young 率の換算式(クよって硬さの公称值から供 試材の Young 率を計算すると，硬度 50 では2.53MPa となる。 本実験で計测した値はこれの約 3.3 倍であった.これは, 薄 いシート状の素材を製造する際の工程の影響などが要因と して考えられる。

さらに, 本実験で Young 率を同定するために必要な押込み 荷重は約 $0.1 \mathrm{mN}$ ，押込量は $0.4 \mu \mathrm{m}$ であった(図 2)ため,この 装置を用いる際に厚さが約 $0.4 \mu \mathrm{m}$ 末満の薄状試料の力学的 特性も計剆可能であることが示唆された.

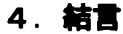

本研究では, 薄状組織の柔さを計测するために, 球圧子押 込試験の原理を適用した. その結果, 厚さが $0.1 \mathrm{~mm}$ レベル のシリコーンゴムの Young 率を計測することができた.さら に, 実験の結果により, 厚さが約 $0.4 \mu \mathrm{m}$ の薄状組織を計測 することができると考えられる. 今後は神経細胞を培養し， 神経線維 $(\phi=0.5 \sim 20 \mu \mathrm{m})$ の Young 率を計測し, 神経線維の 有限要素解析を行っていく.

なお本研究は, 日本学術振興会の科学研究費 - 基盤研究 (B)(課題番号:22360045)の援助の下で実施している.

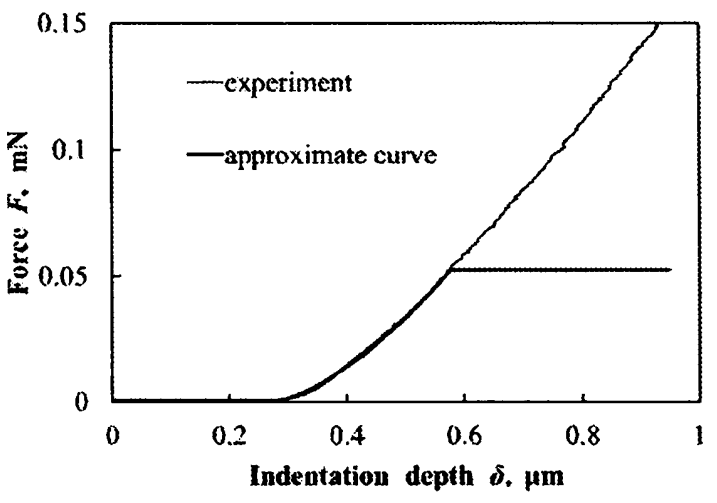

(a) $h=0.1 \mathrm{~mm} \quad E=8.46 \mathrm{MPa}$

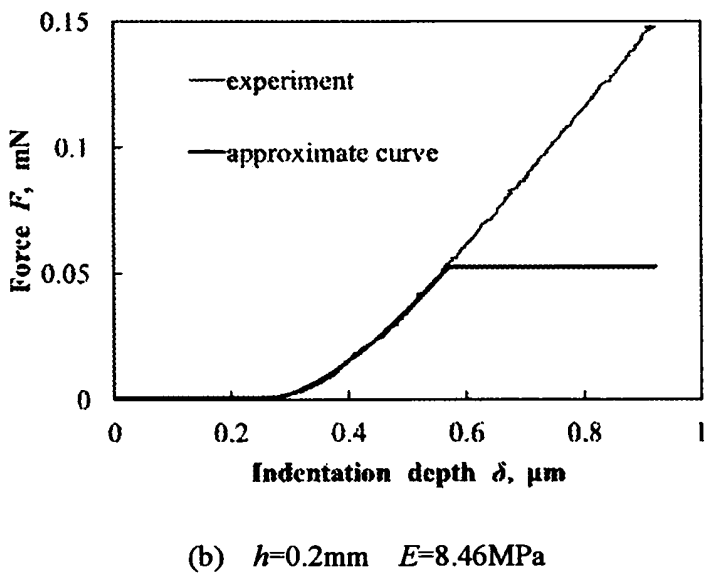

Fig.2 Experimental force-indentation depth curves.

Table 1 Experimental results comparison with durometer hardness

\begin{tabular}{c|c|c}
\hline $\begin{array}{c}\text { Thickness } h \\
10^{-3} \mathrm{~m}\end{array}$ & $\begin{array}{c}\text { Young's modulu } E \\
\mathrm{MPa}\end{array}$ & $\begin{array}{c}\text { Durometer hardness } A 50 \\
\mathrm{MPa}\end{array}$ \\
\hline 0.1 & 8.46 & 2.53 \\
\hline 0.2 & 8.46 & 2.53 \\
\hline
\end{tabular}

支考献

(1) Yuelin Zhang et al., Joumal of Biomechanical Science and Engineering, Vol. 6, No. 3 (2011), pp.191-202.

(2) Yuelin Zhang et al., Joumal of Biomechanical Science and Engineering, Vol.5, No.2(2010), pp.119-128.

(3) M. C. Liu, et al., FMBE Proceedings, 31,(2010), 1079-1082.

(4) 柳原辰一郎ら,バイオエンジニアリング学獄講会・セ ミナ一講演蹁文集(2004), pp.275-276.

(5) 谷充博ら, 日本機械学會論文集. $A$ 楄 (2009), pp.901-908.

(6) H. Hertz, Journal fiur die reine und angewandte Mathematik (Crelle's Joumal), 92, 156(1882), 156-171.

(7) 日本ゴム協会, ت゙ム試験法 第3 版, 丸盖出版株式会社 (2006), pp.164-206. 